\section{New Stratosphere Aircraft}

INFORMATron has just been released regarding a twin-engine stratosphere single-seater fighter, the Westland "Welkin", designed to deal with highflying raiders. It is a mid-wing monoplane of $70 \mathrm{ft}$. span, weight $17,500 \mathrm{lb}$., single tail, and generally of conventional aerodynamic form. It is powered by two Rolls-Royce Merlin engines, of 1,650 h.p. each, fitted with two-stage two-speed superchargers sufficient to maintain the power at exceptionally great heights. Rotol four-bladed constant pitch airscrews are used, giving a speed of 385 miles per hour with a range of 1,500 miles. Its armament consists of four cannon, and the pressure cabin is fully armoured.

It is appropriate that this, the first stratosphere fighter to be adopted by the R.A.F. as a standard type, should have been designed and produced by the Westland Aircraft Co., which has specialized in the problem of high flying and was responsible, in pre-war years, for the equipment of the Mount Everest flying expedition. Many problems upon the design of pressure cabins have been solved in the experimental work on the "Welkin" that will be equally important to civil aviation. The automatic regulation of the air pressure is done by a valve developed by the firm, which is already being used on many other aircraft. Cabin heating and the avoiding of ice and mist formation on the windows is done by means of a 'heat sandwich'; warm air is pumped between two layers forming the pressureresisting surface of the cabin, the same air circulating in the cabin and cockpit space. The temperature control has been found to be such that no special elothing was needed even at an outside temperature of $-78^{\circ} \mathrm{F}$. At ordinary altitudes, either lower temperature than outside can be maintained or even cooled air can be circulated.

\section{Geography in New Zealand}

DURING recent years the study of geography has won recognition in most of the colleges of the University of Now Zealand, and in 1944 a New Zealand Geographical Society was founded in Wellington with branches in the other main cities of the Dominion. This Society has now issued the first number of its joumal under the title of the New Zealand Geographer, from its publishing office at Canterbury University College, where the idea of the Society was born. The journal, which is to appear twice a year, is to be concerned primarily, but not exclusively, with aspects of New Zealand, and is for home and overseas readers. The furst number is devoted entirely to New Zealand topics and is written wholly by New Zealand contributors. Among several important articles is one by Mr. P. D. Sears on the regional variety of pasture growth in New Zealand. Since the country is primarily agricultural with chief interests in grazing, this study of the varying conditions of pasture growth is of much value. Another useful article is by Prof. C. A. Cotton on the geomorphic provinces in New Zealand. The New Zealand Geographer is well produced and promises to be a useful addition to geographical serials.

\section{Bibliography of British Industry}

A SELect Bibliography on "British Industry and Commerce: Its History and Reconstruction" has been issued by the Sheffield City Libraries, to which Lord Riverdale contributes an introduction paying a deserved tribute to the services rendered to industry in the Sheffield district by the Science and Technology Library of the Sheffield City Libraries. The value of this service is well known to the research workers of the larger firms; but Lord Riverdale points out that Sheffield has in its Central Library one of the most valuable and effective research libraries on iron and steel in Great Britain. The bibliography is not limited to books and pamphlets but includes articles appearing in the more important reviews and scientific or technical periodicals during the last three years. Sections on Government and industry, effects of science and inventions on Society, statistical records, location and planning of industry, industrial research, research and education, British trade and commerce, finance and monetary reform and social security are included, but the bulk of the entries are arranged in the three subsections, history, pre-war organization and reconstruction, under the sectional heading British Industries and Public Services. The only important omission in the history subsection appears to be Sir John Clapham's recently pub. lished history of the Bank of England, but the absence of historical records of even large firms is noteworthy. The bibliography is admirably produced and printed; it faithfully reflects the trend of current thought in the fields covered and can be commended as an excellent basis for wider reading and study by those who wish to gain a clearer knowledge of the social and economic background in which scientific and technical research and industrial development proceed.

\section{Azerbaijan Academy of Sciences}

$J_{A C O B}$ GIK, writing from Moscow, states that an Academy of Sciences has now been founded in Azerbaijan. Prior to its establishment, the Republic had a branch of the Moscow Academy, with twentytwo research institutes, ete. The new Academy has four main departments : agriculture, biology, geology and chemistry of oil, physics and technology of oil, together with a department of social sciences. The natural resources of Azerbaijan are now well known. Immense oilfields have been discovered and are now being developed. Geologists are investigating deposits of chromite, barytes and cobalt. The efforts of Russian men of science have made the province to a large extent independent of imported materials and enabled industry to carry on its work during the War without serious interruption. Physicists did particularly valuable work during the War. The Institute of Botany has published a comprehensive scientific work: "Agricultural Raw Materials of the Soviet Union". The Institute of Zoology is doing intensive work on problems connected with the effort to increase the yield of cotton, to rationalize the use of winter pasture lands, and to employ suitable local mineral fertilizers. A history of the literature of Azerbaijan from ancient times has just been published in two large volumes. The statutes of the Academy have been approved and fifteen well-known savants have been named as its first members.

\section{Royal Society of Edinburgh}

AT the ordinary meeting of the Royal Society of Edinburgh on July 2, Sir William Wright Smith, president, presented to the Society, on behalf of the subscribers, a bronze portrait head, by Benno Schotz, of Sir Edmund Whittaker, president of the Society during 1939-44. A copy will also be presented to Sir Edmund Whittaker. Mr. Stanley Cursiter presented to the Society a copy of his portrait of Sir 